University of Warwick institutional repository: http://go.warwick.ac.uk/wrap This paper is made available online in accordance with publisher policies. Please scroll down to view the document itself. Please refer to the repository record for this item and our policy information available from the repository home page for further information.

To see the final version of this paper please visit the publisher's website. access to the published version may require a subscription.

Author(s): Mark Harrison

Article Title: Prices, Planners, and Producers: an Agency Problem in Soviet Industry, 1928-1950

Year of publication: 1998

Link to published version: http://www.jstor.org/sici?sici=00220507(199812)58\%3A4\%3C1032\%3APPAPAA\%3E2.0.CO\%3B2-L

Publisher statement: None 


\title{
Prices, Planners, and Producers: an Agency Problem in Soviet Industry, 1928-1950*
}

\author{
MARK HARRISON ${ }^{* *}$ \\ Department of Economics \\ University of Warwick
}

\begin{abstract}
Soviet planners developed the "unchanged prices of 1926/27" to facilitate the solution of an agency problem -- the regulation of self-interested producers as they worked to fulfil plans for heterogeneous products denominated in rubles. The system limited but did not eliminate producers' opportunistic behavior, which took the form of inflating the plan prices of new products. Through the 1930s and 1940s the "unchanged" prices proved resistant to reform, and following their abolition in 1950 the system was soon afterwards reinstated with a new base year. The history of the "unchanged" prices illustrates the limits of command.
\end{abstract}

* Published in the Journal of Economic History 58:4 (1998), pp. 1032-62.

*** Mail: Department of Economics, University of Warwick, Coventry CV4 7AL, England. Email: mark.harrison@warwick.ac.uk. I am deeply grateful to Elena Tiurina, and Andrei Miniuk, Director and deputy Director of the Russian State Economics Archive (RGAE), Moscow, for access to documents and expert assistance without which this research could not have been attempted. I thank also R. W. Davies, Charles Feinstein, Gregory Grossman, Melanie Ilic, Michael Kaser, Peter Law, Joel Mokyr, Jeffery Round, and two anonymous referees for other help, advice, and comments on various drafts; participants in the Economic History Workshop of the University of Warwick for helpful discussion; and the UK Economic and Social Research Council for funding under research grant no. R000235636 (principal investigators: R. W. Davies and E. A. Rees). 


\section{Prices, Planners, and Producers: an Agency Problem in Soviet Industry, 1928-1950}

Between 1928 and 1950 Soviet production was planned using the "unchanged prices of 1926/27". When plans for output were compiled and results reported, while some significant indicators were also given in physical units, it was the "unchanged" prices which supplied the common standard of value.

The "unchanged" prices were of a special kind. They were in official use for more than two decades, and within a few years of their introduction there were tens of thousands of them. Only a minority of these prices had originated in real transactions involving the exchange of commodities for cash in the year 1926/27 (until 1931 the Soviet "economic year" ran from October to September, from one harvest to the next). The rest were invented retrospectively. Moreover, the "unchanged" prices carried out few of the functions attributable to prices in market economies; they were effective within the confines of government administration, where they were used for a unit of account, but nothing was valued at "unchanged" prices for sale or transfer, and no currency circulated that was denominated in them. The "unchanged" prices were not intended to convey information to producers or consumers about relative scarcities, nor to guide allocative decisions, nor did they have any direct influence on the formation of factor incomes. Because the "unchanged" prices formed important indicators of success for most state-owned enterprises and production-branch ministries, economic agents were often rewarded in some proportion to performance measured in "unchanged" prices, but the rewards themselves were denominated either in kind or in cash at prevailing prices.

The "unchanged" prices were quite distinct from the prices currently prevailing in the Soviet economy at any given time, wholesale and retail, regulated and free-market. These currently prevailing prices played important roles, even in a planned economy subject to widespread state monopolies, substantial compulsory government procurement, administrative rationing of most producer and some consumer goods, and heavy indirect taxation. In particular, prevailing prices formed factor incomes and allocated purchasing power.

Despite such limitations, the Soviet "unchanged prices of 1926/27" were of both practical and historical significance. Being the standard of value used for internal reporting of production outcomes in the microeconomy, they also provided the basis for the national income and industrial production aggregates published officially and reported in Table 1. When the Soviet statistical office claimed that between 1928 and 1950 Soviet national income had multiplied by more than eight times, and industrial production by more than 11 times in real terms, these claims were denominated in the "unchanged prices of 1926/27." Since most western observers suspected such claims of exaggeration, the "unchanged" prices became seen in the West as, in some way, a mechanism for hidden inflation in the officially published figures. ${ }^{1}$ Thus, Russian economic historians best know the "unchanged prices of $1926 / 27$ " in connection with the measurement of Soviet real growth and the problem of hidden inflation.

$<$ Table 1 near here>

The original purpose of the "unchanged" prices was not, however, to provide statistics either for public consumption or for historical analysis. The fact that such figures were published proved to be important, incidentally, in determining how the "unchanged" prices 
evolved, but their primary function was internal to the Soviet economic bureaucracy. The "unchanged" prices were meant to provide a mechanism for the hierarchical regulation of self-interested enterprises under public ownership.

The measurement difficulties created by the "unchanged prices of 1926/27" are therefore important for two kinds of bread-and-butter economic history. On one side are the tasks of real growth measurement and growth accounting. On the other is the business of understanding the behavior of economic agents setting prices and allocating quantities in their historical and institutional context. The present study deals with economic measurement not from the point of view of evaluating historical growth series but as an element in "The Principal's Problem". 2 The unit of analysis is the transaction between agent and principal, not the macroeconomy. A better understanding of hidden inflation may be a by-product, but the implications for Soviet growth accounting must be left to one side for the time being. ${ }^{3}$

The present study is documented from the archives of the former Soviet planning commission and statistical office. The statistical office was named TsSU (the Central Statistical Administration) until 1930 and from 1941 onwards. In the intervening years the authorities frowned upon the application of statistical inference to a planned economy, and the profession of "statistics" acquired negative political connotations. For almost two years, in 1930 and 1931, the statistical office had no independent existence. Between 1931 and 1941 it existed under another name, TsUNKhU (the Central Administration for National Economic Accounts), directly subordinate or attached to Gosplan (the State Planning Commission). Among the tasks of TsUNKhU-TsSU at various times were the collection, aggregation, and analysis of statistical returns denominated in "unchanged" prices, the registration or approval of the "unchanged" prices themselves, and periodic evaluation and review of the system of "unchanged" prices.

The documentary sources are files held by the Russian State Economics Archive (RGAE), Moscow, in fond 1562 (TsSU) and fond 4372 (Gosplan). They fall, roughly speaking, into four categories. First, government decrees and other regulations were drafted within, and subsequently received back by the planning and statistical offices for action or for forwarding to the production ministries; these set out and thereafter revised the methodology for formation of the "unchanged" prices. Secondly, many "unchanged" price lists of successive years were forwarded from the production ministries to the statistical office for filing or approval; given the run of years, and the coverage of tens of thousands of commodities, these constitute raw data in bulk. Third, the statistical office engaged in copious correspondence with the production ministries concerning breaches of the methodology for "unchanged" price formation or apparent anomalies in particular "unchanged" prices. Fourth, planners and statisticians were commissioned from time to time to survey the system, analyse its effectiveness, and review its merits and defects.

\section{THE SEARCH FOR A FIXED STANDARD OF VALUE}

For present purposes, consider the "principal" in the principal-agent relationship to be the planners, Gosplan and TsUNKhU-TsSU. The "agents" were the producers: supply commissariats or ministries to which the production establishments of the public sector were subordinated. Naturally, this principal-agent characterization greatly simplifies both the structure of central planning in the Soviet hierarchy and the complexity of production establishments. Conflicts of interest arose, on the one hand, between the planners and the central authorities to which they were subordinated (the Central Committee and its Politburo, and the Council of People's Commissars, later Ministers), and, on the other, among production establishments and within workplace hierarchies (plant managers and workers). ${ }^{4}$ 
However, these other conflicts are not essential to our understanding of the principal-agent problem which the "unchanged" prices were primarily intended to address.

The respective motivations of principal and agent may be set out as follows. At the centre, the regime was bent on the rapid transformation of the economy and society, a process which was termed "socialist construction". Obedient to their terms of reference, planners struggled to increase production generally from given productive capacities, and the production of capital goods in particular. Producers, on the other hand, aimed to live quietly and get paid without too much effort, rather than to add to output or to capacity utilization, let alone to the surplus of resources for capital accumulation.

A number of classic ingredients of moral hazard were present in this situation: incomplete contracts, differential information, hidden action, risk-aversion, and the sharing of risks. ${ }^{5}$ The production plan was a highly incomplete contract imposed by planners compulsorily on producers. Stalinist political economy at first aimed to supplant the market altogether, but the costs of administrative contracting for production in kind, completely ignored in the utopian thinking of the early Bolsheviks, were in reality very great. ${ }^{6}$ Planners started from key targets for products such as electricity, steel, coal, and oil, which could be specified in physical units -- tons and kilowatt-hours. But the range of products which could be planned effectively in crude physical terms was very narrow. Only in the exceptional case of electric power was the output of an entire industry sector nearly homogeneous. Most enterprises produced many different products. The product assortment of industry as a whole would soon be measured in tens of thousands. On the other hand, the planners' capacity to process detailed information about the physical supply and use of more than a few basic products was strictly limited. In order to ease the information overload, planners engaged in much adding up of heterogeneous products using ruble prices for aggregation, and a great many plans and success indicators were denominated in rubles.

The distribution of information in this system was highly skewed. Planners used less information about physical output than is commonly realized. Their abilities to observe production capacity and producers' efforts were also limited. When production fell short, they had little possibility of knowing whether the shortfall was attributable to reduced effort, capacity constraints, unobserved shocks, or their own errors. Producers were therefore well placed to exploit both hidden information and the possibilities of hidden action so as to improve the ratio of reward to effort. ${ }^{7}$ Producer opportunism was exercised to the detriment of industrial and household users of industrial products. But users were powerless to effect a market solution to the incompleteness of production contracts, because the state had entered into an overriding contract with risk-averse production enterprises to guarantee their markets through state procurement and their revenues by means of the famous "soft" budget constraint. $^{8}$

The literature on the operation of the Soviet-type enterprise suggests several well-known variants of producer opportunism, which I will term lying, fulfilling to the letter, complaining, concealing, and underperforming. ${ }^{9}$ All were designed to tilt the reward-to-effort ratio to the benefit of the producer. Most direct in its influence was lying -- the outright falsification of production returns. Short of lying, producers could also improve the reward-to-effort ratio by fulfilling the plan to the letter, but no more -- focusing effort exclusively on the aspects of production measured in the quota, to the neglect of the unmeasured ones. These two methods worked to raise planners' evaluations of current performance, whereas the remaining three acted to lower planners' expectations. With lower expectations, planners would reduce assignments for planned output or increase allocations of capital, labor, and materials. Maintaining an atmosphere of low expectations required producers to adopt a consistent stance of complaining about the impossibility of assigned 
tasks while withholding information concerning true production capacity. Complaining about assignments while concealing capacity in turn required credible support; this was created by underperforming so as to establish a record of low productivity. The credibility of this record relied in its turn on the planners' inabilities to distinguish between low capacity and low effort. Planners were unable to detect those cases where enterprises were engaging in shirking rather than genuinely constrained by lack of capacity.

The state therefore bore not only the risks of uncertain production outcomes, but also the costs resulting from opportunistic behavior by producers. Under these circumstances, risks and costs could be shared with producers only by means of artificial incentives and punishments. Incentives took the form of plan-related bonuses and other premia; these were usually based directly on plan assignments which were deliberately ambitious, but could also be combined with periodic contests among producers to "fulfil and overfulfil" the plan. ${ }^{10}$

Punishments were triggered by plan failure, but did not take the form of enterprise liquidation or labor redundancy. Firing was an ineffective sanction given the high demand for labor, and enterprise closure was precluded by the softness of budget constraints. Instead, sanctions commonly took the form of the removal of bonuses coupled with the threat of police investigation to uncover shirking. ${ }^{11}$

These rewards and punishments did not eliminate opportunism. They did, however, ensure that all forms of opportunistic behavior faced rising costs, whether in terms of the nonproductive effort intrinsic to the behavior, or the risk of retribution, or the costs of avoiding retribution. Compare, for example, two kinds of opportunism which in themselves were relatively effortless: lying, and underperforming. Lying could be regarded as covert underperforming (the underperformance is concealed in order to secure the bonus and avoid unpleasantness). In the case of overt underperforming, the agent sacrifices the current bonus as an investment in lowering the principal's expectations for the future. The normal punishment for underperforming was the automatic removal of bonuses; this penalty was mild, although the likelihood of detection was high. There was also a smaller risk of additional unpleasantness which could only be temporary provided that the strategem succeeded. Taken too far, however, underperforming would invoke the principal's disbelief and more sweeping retribution. This risk kept overt underperformance within limits, but also made lying more attractive. Lying, being a hidden action, could not be punished just by witholding bonuses. At the same time, for lying to remain hidden required other agents -downstream enterprises, for example -- to collude with the liar for the sake of goodwill by not blowing the whistle. Such collusion greatly reduced the risk of detection and represented a threatening combination from the standpoint of the principal. Therefore, lying was limited partly by the threat of harsh punishment for the smallest uncovered lie and partly by the cost to the liar of winning the goodwill of other agents which rose with the scale of the lie and the potential returns to whistle-blowing.

In short, a purpose of regulation was to ensure that producers faced rising costs to all forms of opportunism without exception, and that these costs could quickly be pushed up to a point where it would be worthwhile for producers to put in some productive effort too.

This general setup emerged with surprising rapidity in the transition away from mixed ownership and a substantial element of market allocation to a state-socialist system under hierarchical, quantitative controls. The main elements -- aggregated output plans, plan-related bonuses, and a punitive response to plan failure -- had all taken shape by the end of the first Five-Year Plan (1928 to 1932). ${ }^{12}$

Detailed arrangements, on the other hand, continued to evolve in subsequent years as the regime searched for mechanisms which would promote efficient regulation and monitoring. At the same time producers searched for new forms of discretion. The pressure 
for improvement was relentless. However, as will become apparent, real change in these arrangements was sporadic and ineffective. The possibilities of improvement were sharply constrained by "the rules of the game", as Oliver Williamson has called the overall institutional environment. To this extent the experience bears out Williamson's distinction between "the immense difficulties of changing the institutional environment in order to promote economizing outcomes in the aggregate" and the ease with which economic agents "align transactions with governance structures to effect economizing outcomes". ${ }^{13}$

Of crucial importance among the detailed arrangements were those which supported the planners' abilities to distinguish plan fulfilment from plan failure. Accurate measurement of real growth was intrinsic to solving "the principal's problem" in the emergent Soviet planned economy. As production controls proliferated, planners urgently required a new fixed standard of value to enable the setting of production quotas comprising many heterogeneous products and the monitoring of their fulfilment by economic agents. Index number theory tells us that real output is always ambiguous, but regulators were intolerant of statistical ambivalence and demanded a single fixed standard by which to judge performance.

Such a standard was not provided by currently prevailing prices, because the environment was strongly inflationary and producers would have fulfilled plans fixed in nominal terms with much less effort by raising prevailing prices rather than quantities. "Fulfilling the plan to the letter" through price increases would have been just as effective in improving the producers' reward-to-effort ratios as the other strategems already outlined, and would have involved them in less risk and nonproductive effort than lying, complaining, concealing, and underperforming. For their part, planners had to shut off the possibility of an effortless, riskless form of opportunism. They had to be sure that the currency in which plans were fulfilled was the same as that with which those plans had been assigned. In effect, plans denominated in rubles required a nominal anchor. Planners sought this nominal anchor in the prices of a fixed base year. The choice of a base year then became a defining issue in the careers, not to mention physical survival, of Soviet statistical and business personnel.

In the 1920s Soviet measures of real product growth, and of the real output of the Soviet economy compared with the levels achieved by the Russian empire before World War I, were typically based on 1913 prices. But by 1928 the prewar base year was seen to have become obsolete; the period before World War I was increasingly distant, and there was a growing range of new industrial products for which "1913" prices had to be invented -- a procedure which, as one commentator put it, included having to estimate the cost which would have been incurred in 1913 to make products not yet invented using technological processes which had not yet been developed. ${ }^{14}$ New regulatory tasks were being superimposed on existing statistical ones. Given that most current industrial products had not been in production in 1913, these prewar prices could scarcely be adapted to meet the new needs of economic regulation. There was a self-evident need for a new baseline.

The first Five-Year Plan was eventually compiled not in current prices, nor in fixed prewar prices, but in the prices of a new base year, 1926/27. ${ }^{15}$ Where ruble figures for planned output of subsequent years were concerned, the prices used to weight them were to remain "unchanged". Planners were now able to fix ministerial and enterprise quotas in terms of the gross value of output (GVO) at "unchanged" prices. From then on, both monetary and nonmonetary rewards would be distributed largely according to the degree of fulfilment of these quotas.

Would the "unchanged prices of 1926/27" provide the nominal anchor or fixed standard of value which the planners sought? Within a few years, the new system would be afflicted by the same problem as the old system based on prewar prices. The new prices were called prices of " $1926 / 27$ " but, with frequent model changes and the introduction of new 
products, it was soon the case that only a small subset of those in use had ever been employed in a realized commodity transaction in the year 1926/27 itself; a growing and eventually dominant proportion had to be invented subsequently. As a result, the fixed standard which the planners sought proved elusive. The "unchanged prices of 1926/27" were less a nominal anchor than a steadily inflating balloon. On the other hand, the balloon did not inflate without limit.

\section{THE INFLATIONARY MECHANISM}

\section{The dimensions of regulation}

By 1933 the new system of "unchanged" prices had become associated with significant regulatory problems. The product prices in which producers' performance was measured were "unchanged", but this did not eliminate the scope for producers to behave opportunistically. Producers sought to exploit disparities in the relationship between "unchanged" product prices and prevailing costs to their own advantages. In addition, there was a contest between producers and regulators for control over the setting of new "unchanged" prices. As a result, planners controlled the relationship between producers' efforts and rewards with growing difficulty.

One way of classifying these difficulties is in relation to existing products, upgraded products (when the attributes of existing products are changed incrementally so as to satisfy existing wants more efficiently), and new products. There is some point at which the differentiation of products creates new attributes which satisfy new wants. The creation of new attributes results in new products, but these distinctions are loose and become looser still in a seller's market. When markets work well, product innovation is market-tested. Upgraded and new products will find a market and command a premium only if the premium corresponds to the enhancement of their attributes. In the Soviet seller's market, however, producers were guaranteed a demand for their products regardless of whether product change represented improvement or deterioration. The proportionality of prices to marginal rates of substitution within the product assortment could not be presumed. In the case of new products -- or products which were claimed to be new -- the explanation of price change became fuzzy: was a given increase justified by the extra utility derived from a new attribute which was previously unavailable at any price, or was it just inflationary?

The official recording of product attributes was notably incomplete. Unmeasured attributes gave further scope for producer opportunism. Products may be characterized by attributes of capacity and attributes of performance. Capacity attributes are evident at the moment when the product is accepted by the user. For consumer goods these attributes would include size, weight, color, finish, uniformity, variety; for machinery, cubic capacity, power-to-weight, volts and watts. Performance attributes such as durability, energyefficiency, and fitness-for-purpose, become evident only later when the product is already in use. In the seller's market, capacity attributes were much more easily controlled than performance attributes. Performance attributes were commonly ignored in product documentation. Those capacity attributes of Soviet machinery which were recorded improved more or less continuously during the 1930s, but performance attributes probably followed a U-shaped path with deterioration under the first Five-Year Plan followed by recovery. ${ }^{16}$

Corresponding to the distinction between existing, upgraded, and new products, the three regulatory problems associated with the early years of the Soviet system of "unchanged" 
prices were the issues of multiple pricing of existing products, the adjustment of prices to product upgrading, and the pricing of new products.

\section{Existing products}

From the start, plan prices were never fixed directly by the planners, although they subsequently became the object of much negotiation and amendment. Rather, planners issued instructions to be followed by producers. Thus "unchanged" prices were fixed at the enterprise level. For existing products they were supposed to be the historical prices of $1926 / 27 .^{17}$ But in the market-economy conditions of 1926/27, different prices had been charged for identical commodities by different producers and to consumers in different localities. Subsequently, under the planned economy, multiple pricing of identical existing products created scope for opportunistic behavior in some ministries. By forcing output where the ratio of the historic "unchanged" price to current costs was relatively advantageous, ministries could fulfil their ruble output plans with less effort. ${ }^{18}$

\section{Upgraded products}

In some branches, a single average "unchanged" price was credited to enterprises for several different grades of output. The enterprise's assortment plan specified the detailed mix of grades to be produced, but the planners' information overload made the assortment plan more difficult to control than the gross-value-of-output plan measured in rubles and "unchanged" prices. Rewards were linked to the output plan, not the assortment plan. Enterprises which concentrated on higher-grade products were penalized by a reduced ratio of rewards to effort. Alternatively, enterprise targets for gross value of output could be met with less effort by biasing the assortment towards lower-grade products. Naturally, such behavior was rarely admitted. Rather than gloat over the returns to strategic behavior, producers complained of the loss of rewards involved in not behaving strategically. ${ }^{19}$

\section{New products}

The years after 1928 saw widespread product innovation in Soviet industry, especially, though not exclusively, in machinery. Much of this innovation was associated with the substitution of domestically supplied machinery products for machinery previously imported. While we lack any comprehensive measure from that period, it was being said by the mid-1930s that the number of commodities being produced which could be matched with the assortment of 1926/27 was already "comparatively small". ${ }^{20}$ This created the problem of how to price new products on a "1926/27" basis when compiling plan quotas and the reports by which plan success and failure were measured.

In fixing the "unchanged" prices of new products, more than for other products, the initiative lay with the producer. In the early years, producers were supposed to fix the "unchanged" prices of new products on the basis of either "the [wholesale] price relating to the initial moment of mass production of the given type of product, or the average for the first three months of its manufacture". ${ }^{21}$ As a result, new products were usually valued at the high costs characteristic of pilot production in the early phase of the innovation cycle, when volume was low and the markup for overheads was high. ${ }^{22}$ Once new-product costs began to fall with mass production, the enterprise could fulfil a given GVO quota made up by new products with much less effort than with old products at "unchanged" prices based on high volume and low unit costs. ${ }^{23}$ Thus one way for producers to reduce effort and still fulfil the GVO quota to the letter was to incorporate new products into GVO at as high an "unchanged" 
price as possible. ${ }^{24}$ The basis of such claims was the pilot costs themselves, and the primary information about them which was held by the enterprise. With enterprises in charge of the fixing of "unchanged" prices for new products, surveys revealed many arbitrary disparities in procedures, practices, and outcomes. ${ }^{25}$

Once "unchanged" prices were fixed, another strategem for enterprises and ministries was then to switch effort to new products with an enhanced reward-effort ratio. One might suppose that here the planners had stumbled on a mechanism to encourage and reward product innovation. But this was probably neither the intention nor the result -- not if we think of "real" innovation which results in a net welfare gain of utilities over costs. As far as results are concerned, under seller's market conditions it did not matter to the producer whether the innovation resulted in an utility gain or loss, so long as a cost increase could be claimed. In this connection, Joseph Berliner described "simulated innovation": the enterprise relaunches old products with insigificant changes, or changes for the worse, solely in order to shift the enterprise to a new-product regime of higher "unchanged" prices. "Real" innovation required the producer to bear significant setup and production costs, whereas simulated innovation required of the producer only a repackaging of existing activities together with an investment in the regulator's goodwill and acquiescence. The distinction between "real" innovation and pure simulation is not hard and fast in practice. Simulation became a recognized form of producer opportunism only in the postwar years. There is no direct evidence for it from the 1928 to 1950 period. But Richard Moorsteen did find Soviet industry in those years to be characterized by technological conservatism. ${ }^{27}$

Whatever the outcome, did planners intend to encourage innovation? Again, probably not. Consider this issue in the wider context of the comparative costs to producers of alternative strategems for improving their reward-to-effort ratio. Lying, concealing, complaining, and underperforming all involved significant risks and nonproductive efforts. These risks and efforts raised the costs of opportunism to the point where there would be some return to producer utility from also putting in some productive effort. The existence of the "unchanged" prices similarly prevented producers from meeting the increase in their ruble targets at no effort or risk by simply putting up the prices of existing products. If they wished to inflate their fulfilment figures, producers were forced to engage (or appear to engage) in some kind of innovative activity and this, whether or not it benefited society, would be costly in terms of producers' utility. It is consistent with this approach that, in most other respects, the environment of the Soviet producer was notoriously detrimental to innovative activity. ${ }^{28}$ Eventually the costs of product innovation, whether real or simulated, would rise to a point where producers would find it worthwhile also to engage in the production of existing products.

\section{"Unchanged" prices and inflation in prevailing prices}

Soviet commentaries, whether public or classified, did not mention a further complicating factor of which their authors were surely well aware. This was the general, unconcealed inflation which was already under way and accelerating in 1928, and which persisted through the 1930s. For example, the implicit GNP deflator obtained from Bergson's recomputation of the Soviet national accounts shows a rise of between three times (using 1937 quantity weights) and more than five times (using weights of 1928) between 1928 and 1937. The inflation was not uniform. There were large relative price effects within the aggregate, with retail product prices multiplying several times, the prices of basic industrial products rising substantially, and machinery prices rising somewhat or even falling depending on the weights used. ${ }^{29}$ The trend of machinery prices might be thought significant given the 
high incidence of product innovation in that sector; but whatever the absolute level of machinery prices after 1928, the significance of the general inflation was to raise the prices of new machinery products above the level at which they would have been introduced had the overall price level remained stable. Thus the price level at which new products were chained into gross output at "unchanged" prices was inflated relative to the historical 1926/27 level not only by the high relative costs of pilot production, but also by the rising level of all costs. ${ }^{30}$

The "unchanged prices of 1926/27" were not for the most part prices of 1926/27; they evolved in a heavily damped relationship with the prevailing price level. The particular prevailing prices which matter here are the official "factory wholesale prices" at which products of state-owned industry were valued for current intra-industry transactions, net of indirect taxes and distribution costs. Official retail prices were built up by adding on indirect taxes and distribution costs. The regulatory authorities were very interested in getting wholesale prices right. Because these regulators used a cost-of-production theory of value, this meant getting wholesale prices proportional to production costs. However, the relationship between wholesale prices and costs was itself heavily damped by bureaucratic noise and administrative delays, only partially corrected by periodic "reforms" (there was one in March 1936 and another in January 1949; each is discussed later). Wage costs and free market prices for private produce and retraded official products, on the other hand, were relatively sensitive to the balance of supply and demand.

One could thus imagine the inflation of the early 1930s being registered first in the markets for labor and privately traded food and other products, then in the rising direct costs of the products of state-owned industry, subsequently in the upward trend of their prevailing official prices and finally in the rising level at which new products were chained by industry into gross output at the "unchanged prices of 1926/27." Meanwhile, the "unchanged" prices of existing products were left trailing behind the rising level of prevailing prices.

The complex dependence of "unchanged" prices on prevailing prices can be illustrated in a two-product, three-period model. One commodity, an "old" product, is supplied throughout at an unvarying rate. The other is produced not at all in the base period 0 , innovated as a "new" product in period $i$, and mass-produced in period $m$. The gross output at prevailing prices whether of an enterprise, ministry, or industry as a whole in period $t$ $(t \geq i$ ) is given by:

1. Nominal GVO ${ }_{t}=p_{t} \cdot 1+n_{t} \cdot x_{t}$

where for simplicity the output of old products is fixed at 1 , and $x_{t}$ is the ratio of outputs of new to old products; $p_{t}$ is the price of old products already indexed to $p_{0}=1 ; n_{t}$ is the nominal price of new products.

Gross output at "unchanged" prices, with new products chained in at their introduction price, is given by:

2. Official real GVO ${ }_{t}=1+n_{i} \cdot x_{t}$

The dependence of "unchanged" prices on prevailing prices is illustrated by the ratio of official real to nominal GVO:

3. Official real GVO $t_{t}=\left(\frac{1+n_{i} \cdot x_{t}}{p_{t}+n_{t} \cdot x_{t}}\right) \cdot$ Nominal GVO

For simplicity we will restrict consideration to the GVO aggregates of two supply ministries. In the first supply ministry few new products are brought in, so old products continue to predominate $\left(x_{t} \rightarrow 0\right)$. In equation 3 , under this assumption, the coefficient of 
nominal GVO $\rightarrow\left(\frac{1}{p_{t}}\right)$; in other words, in the absence of product innovation "unchanged"

prices are unaffected by prevailing price inflation, showing that their link with the price level of 1926/27 is intact, and official real GVO is simply nominal GVO deflated by $p_{t}$.

In the second supply ministry, product innovation is rapid and new products completely displace the old ones produced in the base year (so $x_{t} \rightarrow \infty$ ). This creates a dependence of "unchanged" on prevailing prices. If we think of the ministry's entire product assortment being renewed continuously and repeatedly, then its enterprises will effectively remain in the innovation period ( $t=i$ ). Official real GVO at "unchanged" prices will simply track nominal GVO (in equation 3 , the coefficient of nominal GVO $\rightarrow 1$ ). The link with the $1926 / 27$ price level is broken. ${ }^{31}$

If product innovation slowed down, the ministry would then enter the mass-production period $m$. With no old products left in production the $\left(x_{t} \rightarrow \infty\right)$ condition still holds, but a gap now opens between the "unchanged" and prevailing prices. In equation 3 , under these assumptions, the coefficient of nominal GVO $\rightarrow\left(\frac{n_{i}}{n_{m}}\right)$; in other words, official real GVO may start to lag behind nominal GVO, because change in the prevailing prices of new products since the pilot phase will not be reflected in GVO at "unchanged" prices. With learning and economies of scale, the prevailing prices of new products are likely to fall relatively, and might even fall absolutely in normal periods, although inflationary times would make the latter unlikely. However official real GVO is to be deflated by recent change in the prices of new products, any link with the price level of 1926/27 was already dissolved in the earlier period when the old products were displaced by the new ones.

$<$ Table 2 near here>

This pattern is precisely what we find in the official data. Table 2 shows industry GVO at prevailing and "unchanged" prices in 1935 divided among the responsible people's commissariats, of which heavy industry was the most important (in Soviet parlance heavy industry included machinery, metallurgy, construction materials, fuel, and power). By 1935 the official real GVO of industry at "unchanged" prices (col. 1) was lagging significantly behind nominal GVO (col. 2), but the lag was concentrated almost entirely in the light and food industries, where product innovation was slow. In heavy industry (including machinery), on the other hand, GVO at "unchanged" prices shadowed nominal GVO with uncanny closeness. In subsequent years this relationship was modified as will be shown.

\section{A CONSERVATIVE REFORM}

\section{The reform process}

By 1933 there was substantial pressure among statisticians for change. Some of them apparently considered that 1926/27 was already obsolete as a base year. The public record shows that the critics of 1926/27 were attacked twice in print in 1934 and 1935, and no sooner had they been defeated than criticism resurfaced in $1936 .{ }^{32}$ In the main commissariats for large-scale industry the system was a mess. Other branches (local, cooperative, and artisan industry, state farms and farm procurements, river and rail transport, and the consumer goods output of heavy industry) had either already begun to use 1932 as a base year or still did not use "unchanged" prices at all, requiring their GVO figures to be converted from current or 1932 prices to a 1926/27 basis by means of deflators. ${ }^{33}$ In September 1933 a decree of 
Sovnarkom obliged Gosplan and TsUNKhU to set about a reform. The reform however was to be conservative -- to do what was necessary to make the existing system based on 1926/27 work more rationally, not to shift to another base year or a different formula.

The reform was implemented over 18 months, with the main revisions approved by Gosplan in February 1935, ready for the 1936 plan. ${ }^{34}$ Each of the three incentive problems was supposedly addressed. The fixing of "unchanged" prices was centralized, and new-product pricing was to be more tightly regulated. Instead of enterprises authorizing their own "unchanged" prices, which were also therefore variable across enterprises and regions, unified "unchanged" price schedules (tsenniki) for existing products were compiled at a ministerial level and approved by Gosplan and TsUNKhU for use by all enterprises. For a variety of products new price schedules more carefully graded by quality were authorized. As for products introduced in 1935 or a subsequent year, a procedure for deflating the introduction price to a "1926/27" basis was introduced. The results of this rule were to be approved annually by TsUNKhU, through a new "commission for 1926/27 prices". 35

A conservative motivation was expressed partly in clinging to the 1926/27 base year, partly also in a determination not to have to revise already published series for GVO aggregates and growth trends of ministries and production branches, as would become inevitable if the base year were shifted nearer to the present. This desire was expressed both publicly and privately. In public, the fact that shifting the base year nearer to the present would increase the weight of agriculture and light industry relative to heavy industry was cited as a self-evident argument against change. ${ }^{36}$ In private, as will be shown, officials went to great lengths to ensure that no revisions would significantly affect any data already in the public domain.

The reform of 1935 had the potential to affect producer interests from two angles. One was its revision of procedures for fixing "unchanged" prices of new products, and the other was the revision of prices of existing products.

\section{Existing products}

Francis Seton and Alec Nove both suggest that the reform might have provided the opportunity for a major upward leap in the "unchanged" price level. In their view, any adjustment to the structure of relative "unchanged" prices would release pressure from below for upward revisions, while both planners and producers would resist price reductions which would lower targets and recorded growth rates. ${ }^{37}$ The newly available documentary evidence, however, allows us to reject their hypothesis on several grounds. The nominal anchor was held in place.

\section{The 1-percent rule}

First, TsUNKhU officials aimed to cap inflationary pressure by imposing the rule that, when comparing GVO figures in "old" and "new" unchanged prices, ministerial aggregates should not normally vary by more than \pm 1 percent. ${ }^{38}$ This had two effects. First, if higher prices were sanctioned for some products, the increases had to be balanced by reductions for others within the ministerial assortment. The pressure from below may well have been in an upward direction -- notably, to introduce higher prices for higher-grade products of the timber and food industries. In practice, however, it was successfully contained by the 1-percent rule. A second effect was to avoid revision of any figures for industry GVO and its real growth and composition which were already in the public domain. 
Thus revisions to "unchanged" prices agreed in 1933 and 1934 resulted in amendments to the 1934 plan GVO of three industrial ministries as follows: light industry +0.14 percent, the timber industry +0.7 percent, and heavy industry -0.6 percent, mainly on account of machine-building (-1.3 percent). For the industry total, the net change was "insignificant". ${ }^{39}$ In the case of the food industry there had already been enforced an overall net reduction of more than 5 percent, made up by viticulture (-77 percent), and other branches (+1.7 percent $).{ }^{40}$ In the same spirit, further revaluations of "unchanged" prices in light industry resulted in an overall deflation of 1935 plan GVO by 1.0 percent, with results for different branches varying from -6.9 percent to +13.1 percent. ${ }^{41}$

The ratio of wholesale to "unchanged" prices

Second, Table 3 allows us to judge the success of the operation from variation in the differential ratios of official real to nominal GVO across industry between 1935 and 1936 (the figures for 1935 are those already considered in Table 2). The differences between the two years were formed by two events -- the 1935 reform of "unchanged" prices, and the March 1936 reform of wholesale prices. The latter aimed to eliminate subsidies to industry by raising the wholesale price level. ${ }^{42}$ The outcome shown in the table is that the ratio of "unchanged" to prevailing prices fell back from 0.68 to 0.57 . The incidence of the decline was uneven, but was marked in all the main branches of industry. In heavy industry a gap was opened up between the prevailing and "unchanged" price levels for the first time.

$<$ Table 3 near here>

Thus the reform of "unchanged" prices did not provide an opportunity for an uncontrolled explosion of the "unchanged" price level. If "unchanged" prices were being allowed to rise generally because of permissive revisions associated with the 1935 reform, then there would have been evidence of catch-up in the ratio of "unchanged" to prevailing prices. Instead, the lag increased, and it increased across the board, regardless of whether product innovation was rapid, as in heavy industry, or slow, as in other branches. A plausible interpretation is therefore that in all the main branches of industry where wholesale prices of existing products were being allowed to drift up, their "unchanged" prices were nonetheless being kept under strict control.

\section{Price comparisons for identical products}

The third set of grounds for rejecting the hypothesis that the reform provided an opportunity for a general inflation of existing products" "unchanged" prices is obtained from three samples of products matched in different years before and after the reform. Each sample is drawn up for a different purpose, but none shows any upward drift that could be termed remotely significant.

The samples are not large, consisting of 32, either 36 or 32, and 31 observations respectively. By way of context, consider that there were more than 39,000 "unchanged" prices approved by Gosplan or TsUNKhU for the single year 1934, of which machinery alone accounted for some 17,000 and the heavy, light, and timber industries together for more than $28,500 .{ }^{43}$ Thus the 3 samples may be considered convincing only when taken in conjunction with the other evidence already cited.

Results of $t$-tests for differences in means of paired samples are shown in Table 4. In all cases variables are transformed into their natural logarithms. Sample 4.1 consists of "unchanged" prices for 32 basic products which can be matched from price schedules of 1928 
and 1935. In this case a decline in the sample mean between the two years is just significant at 5 percent.

$<$ Table 4 near here>

Sample 4.2 is drawn from a document of October 1934, which specified the transition from multiple to unified "unchanged" prices in the heavy and timber industries. 31 separate basic products were covered, and, additionally, the old single price for plywood was replaced by 5 separate product prices graded by quality. The "new unchanged" prices of the first 32 products are compared with the arithmetic means of the corresponding "old" maxima and minima for "unchanged" prices of each product. For the 5 plywood products each paired observation links the single "old unchanged" price with a different "new unchanged" price graded by quality. Sample 2(A) includes, and Sample 2(B) excludes, plywood products, where price revisions appear to have been mildly inflationary. In neither case, however, is the increase in the sample mean statistically significant.

Sample 4.3 is drawn from a document of the People's Commissariat of the Food Industry, again from September 1934, detailing revisions to "unchanged" prices. Among the revisions reported are 32 commodities where a direct comparison is allowed between the old and new "unchanged" prices. The mean of natural logs of the new prices is less than for the old prices, and the reduction is just significant on a one-tailed test at 10 percent.

\section{$\underline{\text { New products }}$}

In principle, the reform was intended to rationalize the position with regard to new product prices. Here one might think of the problem in two phases, one of which arose in looking forward, the other from looking back. Looking back, the problem was what to do about all the new products brought in since 1926/27, the "unchanged" prices of which had already been fixed at an inflated level. Looking forward, the problem was how to get the "unchanged" prices of the next generation of new products right in the first place, at the moment when they were formed. Neither problem found a solution, although for different reasons.

\section{New products introduced between 1928 and 1934}

In 1934 and 1935, many examples came to light of products recently innovated the "unchanged" prices of which now appeared unreasonably high in the light of cost reductions attributable to scale economies, learning, and so on. The result was to distort the reward-to-effort ratio of producers able to fulfil plans denominated in "unchanged" prices by concentrating on such new products. Branches commonly mentioned in this connection included machine-building, nonferrous metals, and chemicals, while products specifically highlighted included machinery products, furniture, and leather footwear. ${ }^{44}$

In one document of 1934 we find comparisons between domestic and foreign prices of new products. For metal products generally the ratio of Soviet "unchanged" 1926/27 prices to US prices of 1926/27 was estimated at 1.54 (1.66 if comparators were the UK and Germany), but for new products Soviet "unchanged" prices exceeded import prices by four to five times or more. In the case of individual mining machinery products the ratio to import prices varied between 1.5 to 12 , and for textile machinery from four to six (but in the case of farm machinery, described as more fully assimilated to mass production, not more than 1.2 to $1.3)^{45}$

In practice, however, it was impossible for the regulators to affect substantially the level of new products' "unchanged" prices after the event. They were trapped by their own 
1-percent rule. A significant deflation would lower results already published and plans already promulgated. "Unchanged" prices for furniture could be cut, for example, only because an increase was being sanctioned simultaneously for sawn timber and plywood products on average, leaving the ministerial aggregate roughly constant. ${ }^{46}$ Cases therefore also arose where reductions were pronounced desirable but left unenforced, just in order to maintain continuity with the price regime of the past. ${ }^{47}$

The conclusion of an internal Gosplan review of subsequent practice was that the regulators had been able to interfere only where relative prices of particular commodities were clearly wrong, and had made no attempt to revise the general level of "unchanged" prices because this would have resulted in both "distortion of the evaluation of plan fulfilment and the necessity of revising published time series for industrial output and the proportions of different branches". 48

\section{New products of 1935 and subsequent years}

Here, again, the reformers aimed to have a substantial impact through a new deflation rule which would be applied in all future cases of new products. This rule could be set out formally as follows. As before, there are new and existing products; existing products are those produced before 1935 and new products are produced in 1935 for the first time. The nominal wholesale price of existing products is $p_{t}$, and the wholesale price of new products is $n_{t}$. For each new product, the enterprise was instructed to calculate the "unchanged" price $n_{26 / 27}$ which would then be used in all future plan assignments and fulfilment reports. The "unchanged" price was to be the new product's currently prevailing introduction price $n_{35}$ adjusted to a "1926/27" basis. The adjustment involved a deflator $\delta$ as follows:

4. $n_{26 / 27}=\left(\frac{1}{\delta}\right) \cdot n_{35}$

The deflator was to be computed as the ratio of the 1935 prevailing price to the "unchanged" price of some existing product of the enterprise, defined by the enterprise as analogous "in composition and quality" (po strukture i kachestvu) to the new product:

5. $\delta=\frac{p_{35}}{p_{26 / 27}}$

On paper this made good sense. Had it been capable of implementation, it would theoretically have had the effect of a partial chain-linking of the index of GVO at "unchanged" prices. The correction would have been partial because it would have cancelled out the inflation of new product prices relative to the historical 1926/27 level which was attributable to the rising level of all costs, but not that attributable to the high relative costs of pilot production. In practical terms it would have reduced the scope for producers to improve their reward-to-effort ratio by skewing the assortment towards new products. But it would be wrong to suppose that the intention was to act upon the rate of product innovation by altering incentives. The implications for innovative behavior were never even mentioned. Most likely, the planners aimed at a system of plan prices which would be as nearly neutral as possible in respect to allocation, rather than actively encouraging or discouraging, so that the planners themselves could evaluate real growth more objectively and get on with the business of allocation with a freer hand. ${ }^{49}$

In any case, the new rule proved to be ineffective. The problem, in the opinion of the statistician A.I. Rotshtein, lay in the calculation of new-product deflators. What was analogous "in composition and quality" to the new product remained undefined at the centre, leaving scope for producer opportunism in selecting favorable comparators from among the 
enterprise's existing products. ${ }^{50}$ For each new product several possible comparator products might be available, each with a different deflator. The best comparator could be defined as the one with the lowest deflator. The value of the deflator would be influenced not only by random variation, but also crucially by the comparator's year of introduction -- before or after 1926/27 -- determining the price level at which its "unchanged" price had been fixed. The nearer to 1935 the comparator product had been introduced, the higher would this price level have been and the less deflation would be required in fixing the "unchanged" price of the new product. Thus " $p_{26 / 27}$ " might actually be $p_{34}$. There was no obligation on the enterprise to find a comparator which had actually been produced and priced in 1926/27 itself, and nothing to prevent the selection of a comparator introduced by the enterprise in 1934 with its "unchanged" price based on the higher prevailing costs of that year. Thus, the reform of 1935 left virtually the same scope as before for producers' discretion over new-product pricing.

A further problem about new products which fed back into other aspects of the "unchanged" prices nightmare is that new products soon became old products. The new product priced in 1935 could afterwards serve in its turn as a comparator for the next generation of new products. As "unchanged" prices of new products were introduced first in the enterprise, and only subsequently offered up for high level rubber-stamping, it became virtually impossible for the TsUNKhU commission to keep track of them all, verify them, and unify them. As product innovation proceeded and industry's assortment profile widened, concern about multiple pricing, prices based on excessively aggregated product classes, and huge disparities between "unchanged" prices and prevailing costs continued to be voiced. ${ }^{51}$

\section{FROM REFORM TO ABOLITION}

\section{The aftermath of the 1935 reform}

After the 1935 reform the commission for 1926/27 prices, with tens of thousands of prices to regulate, remained inadequately staffed and funded. It continued to chide producers for following incorrect procedures and to remind them of the obligation to maintain a link with the increasingly remote $1926 / 27$ base. ${ }^{52}$ The 1 -percent rule still frustrated attempts to bring down new-product prices once they had been fixed. ${ }^{53}$ In 1938 the commission chairman (Sobol') and secretary (Liubimov) wrote to Sautin, then chief of TsUNKhU:

In the opinion of many the system of unchanged prices of 1926/27 is becoming obsolete. Thus for example the planning department of Narkommash [The People's Commissariat for Machine-building] considers that the historically established so-called unchanged prices of 1926/27 give a false impression of changes in the volume of output, plan fulfilment, etc. ${ }^{54}$

Under such circumstances the pressure for change in the system of "unchanged" prices could not be expected to disappear. Indeed Rotshtein's significant critique had appeared almost immediately after the 1935 reform (Rotshtein argued that with product innovation any fixed base year rapidly becomes obsolete) ${ }^{55}$ However, there was no immediate further reform. Purges, war mobilization, and postwar reconstruction would come first.

In the meantime the differential lags of "unchanged" prices behind prevailing prices widened somewhat across industry. Table 5 gives figures for benchmark years up to 1950 on a product classification rather than the ministerial classification used for the 1930s in Tables 2 and 3. The gross output of industry is divided into groups " $\mathrm{A}$ " (military goods and civilian producer goods) and "B" (consumer goods). By 1940 a substantial gap had opened up 
between "unchanged" and prevailing prices in all branches of industry. Given the differential opportunities for product innovation the gap was, as predicted, less for group " $A$ " than for group "B", and was least in the case of military products where the assortment turnover was especially rapid under prewar rearmament and military modernization, so that neither the product mix nor the "unchanged" prices retained the smallest link with 1926/27.

$<$ Table 5 near here>

In wartime, the disproportions increased. In the first phase of the war defence industry witnessed further sweeping change in the product assortment, once again drawing the "unchanged" prices of military products after their prevailing prices. Thereafter defence industry entered a mass production phase. With prevailing weapon prices falling sharply, by 1945 the GVO of defence industry at "unchanged prices of 1926/27" actually exceeded its nominal GVO. The volume of war production was large enough to exert a big composition effect on group " $\mathrm{A}$ " and industry as a whole, pulling up the overall ratios of "unchanged" to prevailing prices despite a further decline in the ratio in group " $\mathrm{B}$ " where product innovation had virtually ceased.

In the postwar years there was a sharp recovery of civilian output and civilian product innovation was resumed. In addition, 1949 saw a wholesale price reform push up prices in heavy industry on average by nearly 60 percent (the official figure; for the light and food industries wholesale prices fell slightly). ${ }^{56}$ Once again, prevailing prices pulled away from "unchanged" prices. Even so, in 1950 the pattern of lags remained highly differential, with "unchanged" prices of consumer products falling far behind the prevailing price level, dragged back by a residual link with the product assortment and prices of 1926/27. In defence industry where the link was completely broken, "unchanged" prices lagged only momentarily behind prevailing prices; the "unchanged" prices of civilian producer goods fell in between.

\section{Planning in wholesale prices?}

The final chapter in the history of the "unchanged prices of 1926/27" begins at the end of 1947, when Gosplan initiated a review of the system. ${ }^{57}$ By the postwar years the system had fallen into deep disarray. In wartime military product innovation had proceeded rapidly. Civilian product innovation, having slowed down, was now being resumed in consumer durables as well as machinery. The norm was again for producers to include new products in plan GVO at the high wholesale prices prevailing in the introduction period without any attempt at deflation to " $1926 / 27$ ". Thus, ratios of prevailing to unchanged prices in 1947 were reported to range from 25:1 in some branches of the light and food industries to 1.0:1 in shipbuilding. ${ }^{58}$ Meanwhile, the all-important tsenniki had fallen into disuse, along with the prewar system for registering "unchanged" prices of new products for approval by the centre. Producers tended increasingly to ignore "unchanged" prices already approved and invent their own. Some startling anomalies were reported, with ratios of "unchanged" prices actually in use to those centrally approved in many multiples. ${ }^{59}$ By this time the scope for both statistical distortion and resource misallocation arising from producers' opportunistic responses to anomalies in "unchanged" prices was routinely recognized in official documents. ${ }^{60}$ At the beginning of 1948 the statisticians were also made aware of criticisms of the "unchanged" prices which had been made in the West in the previous year by contributors to a symposium in the Review of Economic Statistics; however, there is nothing in the files to indicate what sense was made of them. ${ }^{61}$

In themselves these pressures could simply have given rise to more of the same: a conservative rationalization of the existing system, as in 1935, with more centralization of "unchanged" price-fixing and more emphasis on rules and methodologies. On this occasion, 
however, the planning chief N.A. Voznesenskii was ready to grasp the nettle. Indeed, the context suggests a link between his postwar advocacy of the role of "economic levers in the organization of production and distribution such as price, money, credit, profit, incentive" and his readiness to abandon " $1926 / 27$ " as a basis for plan prices. Economic levers, to be effective, must be based on prices which bore some proportionality to current costs, not the notional costs of some far distant year. ${ }^{62}$

In the event, a decree was prepared within Gosplan for the government to authorize a transition to the planning of output in prevailing wholesale prices. Linked with this was a reform to bring wholesale prices into line with costs (in particular, to raise prices and eliminate subsidies in heavy industry, where prices had been held down despite wartime and postwar inflation of wages and other costs). Because wholesale prices could change between the moment when plan quotas were fixed and the moment when results were reported, there was still the need for a nominal anchor to ensure that the prices in which plans were fulfilled were the same as those in which they had been assigned -- otherwise producers could "fulfil to the letter" by pushing for product price increases. The nominal anchor would be wholesale price indexes by which results could be deflated to the prices in which the plans had been originally assigned. Both the price reform and the plan reform were to take effect from 1 January 1949. However, transitional arrangements were also put in place for the "unchanged prices of 1926/27" to live on until the end of 1950 in order to facilitate monitoring the fulfilment of the fourth Five-Year Plan (1946 to 1950). ${ }^{63}$

To what extent would planning in wholesale prices have narrowed the scope for producer opportunism? Essentially, it would have removed one of the sources of long-run gain accruing to product innovation. Under the old system, producers could not act upon the "unchanged" prices of existing products, but they could control those of new products by inflating costs generally and the pilot costs of new products in particular. Under the new system, each revision of wholesale prices would periodically confiscate gains to new-product producers by indexing plan prices for existing products to the general level of costs. Thus opportunistic gains to product innovation would only persist between wholesale price reforms. With sufficiently frequent price reforms the results should have been superior to the intention of the 1935 reform, which would have confiscated only those gains to new-product producers arising from the general inflation, not those arising from temporarily high pilot costs. Hindsight reminds us, however, that wholesale price reforms were actually very infrequent, with 13 years between 1936 and 1949, and 17 years to the next reform in 1966.

As in 1935, the point of the 1949 reform was not to penalize or reward innovation itself, and the implications for innovative behavior of going over to planning in wholesale prices were not mentioned. Like his predecessors Voznesenskii aspired to a system of plan prices which would be neutral in respect to allocation, leaving planners to allocate and producers to acquiesce. On the other hand, the new system posed clear problems for control of the general price level -- hence the requirement that plan results should be indexed to the wholesale prices of the original plan to weaken the incentive for producers to raise prices.

It seems significant that these proposals evoked dissent within Gosplan. The minority opinion, signed by I. Pisarev, called for the old "unchanged prices" to be replaced in 1951 by new "unchanged prices" based on 1950. ${ }^{64}$ The majority view was forwarded to the Council of Ministers, approved in a decree of 18 July 1948, and duly implemented on 1 January 1949. Yet the minority opinion ultimately prevailed. After two years of planning with current wholesale prices, from 1953 the economy was again planned with "unchanged" prices, this time based on 1952. The price reform had pushed up wholesale prices in heavy industry and slashed budget subsidies, but within a short period the reform was largely cancelled out by a policy of price cuts. By 1952 wholesale prices for heavy industry were only seven percent 
higher on average than in $1948 .^{65}$ Meanwhile Voznesenskii, who bore ultimate responsibility for both reforms, had been quietly sacked in March 1949 (he was subsequently arrested and executed). The political economy of this switchback course remains at best the subject of informed speculation. ${ }^{66}$

Nostalgia for the old "unchanged" prices remained embedded in Soviet statistical institutions. A decade later, despite the new era of post-Stalin openness, V.N. Starovskii, head of the Soviet Union's statistical organs since 1938, would still speak out in defence of the "unchanged prices of 1926/27" as if the 1935 reform had essentially solved their problems. ${ }^{67}$ The growth rates based on the "unchanged" prices remained sacrosanct for nearly forty years, until the now-celebrated attack on them by Khanin and Seliunin in $1987 .^{68}$

\section{CONCLUSION}

The Soviet "unchanged prices of 1926/27" were originally developed by planners (as "principals") to fix the standard of plan values for regulation of public sector producers (as "agents"). The system of "unchanged" prices was intended to limit the scope for opportunistic producers to fulfill ruble quotas for gross output by raising product prices. In the 1930s and 1940s there was continuous pressure from producers for increases in "unchanged" prices. The authorities contained this pressure with regard to products already sold in 1926/27, but the latter formed a diminishing share of the total. By introducing new or upgraded products, producers exerted an upward influence on the overall level of "unchanged" prices which the authorities were relatively powerless to check. However, the system of "unchanged" prices did limit producer influence over plan values by forcing opportunistic agents to incur the costs of product innovation. The control of "unchanged" prices of new products was not designed to encourage or deter product innovation. Ideally, the planners sought a system of plan prices which would be neutral with respect to allocation while accurately accounting for real growth. This goal proved elusive. At the same time, despite its defects, the system resisted not only reform but even abolition. The history of the "unchanged" prices therefore illustrates clearly the limits of command in the Soviet economic system. 


\section{REFERENCES}

Arrow, K. "The Economics of Agency." In Principals and Agents: the Structure of Business, edited by J. Pratt and R. Zeckhauser, 37-51. Boston, MA: Harvard Business School Press, 1985.

Bergson, A. The Real National Income of Soviet Russia since 1928. Cambridge, MA: Harvard University Press, 1961.

Berliner, J. S. Factory and Manager in the USSR. Cambridge, MA: Harvard University Press, 1957.

—. The Innovation Decision in Soviet Industry. Cambridge, MA: Harvard University Press, 1976.

_. "Planning and Management". In The Soviet Economy: Toward the Year 2000, edited by A. Bergson and H.S. Levine, 350-90. London: Allen \& Unwin, 1983.

Central Intelligence Agency (CIA), National Foreign Assessment Center. An Analysis of the Behavior of Soviet Machinery Prices, 1960-1973, ER79-10631. Washington, DC: U.S. Government Printing Office, 1979.

- Comparing Planned and Actual Growth of Industrial Output in Centrally Planned Economies, ER80-10461. Washington, DC: U.S. Government Printing Office, 1980.

Clark, C. "Russian Income and Production Statistics." Review of Economic Statistics, 29, no. 4 (1947): 215-26.

Davies, R. W. "Industry." In The Economic Transformation of the USSR, 1913-1945, edited by R. W. Davies, M. Harrison, and S. G. Wheatcroft, 131-57. Cambridge, England: Cambridge University Press, 1994.

- The Industrialisation of Soviet Russia, Vol. 4. Crisis and Progress in the Soviet Economy, 1931-33. Basingstoke and London: Macmillan, 1996.

Dobb, M. "Further Appraisals of Russian Economic Statistics." Review of Economics and Statistics, 30, no. 1 (1948): 34-38.

—_. "Comment on Soviet Economic Statistics." Soviet Studies, 1, no. 1 (1949): 18-27.

Gerschenkron, A. "The Soviet Indices of Industrial Production." Review of Economics and Statistics, 29, no. 4 (1947): 217-26.

Gordon, R. J. The Measurement of Durable Goods Prices. Chicago, IL, and London: University of Chicago Press and National Bureau of Economic Research, 1990.

Granick, D. Management of the Industrial Firm in the USSR. New York: Columbia University Press, 1954.

Gregory, P. R. Restructuring the Soviet Economic Bureaucracy. Cambridge, England: Cambridge University Press, 1990.

Harris, S. "Appraisals of Russian Economic Statistics: Introduction." Review of Economic Statistics, 29, no. 4 (1947), 213-14.

Harrison, M. "Soviet Industrial Production, 1928-1950: Real Growth, Hidden Inflation, and the 'Unchanged Prices of 1926/27'.' University of Warwick, Department of Economics, Working Paper no. 9705, 1997.

Harrison, M., and N. Simonov. "Voenpriemka: Prices, Costs, and Quality Assurance in Defence Industry." In The Soviet Defence-Industry Complex from Stalin to Khrushchev, edited by J.D. Barber and M. Harrison. London and Basingstoke: Macmillan, in press.

Hodgman, D. R. Soviet Industrial Production, 1928-1951. Cambridge, MA: Harvard University Press, 1954.

Jasny, N. "Soviet Statistics." Review of Economic Statistics, 32, no. 1 (1950), 92-99.

—. The Soviet Price System. Stanford, CA: Stanford University Press, 1951. 
- The Soviet Economy during the Plan Era. Stanford, CA: Stanford University Press, 1951.

Kaser, M. "Le Débat sur la Loi de la Valeur en URSS. Étude Rétrospective 1941-1953". Annuaire de l'URSS, CNRS: Paris, 1965.

—. "Soviet Planning and the Price Mechanism." Economic Journal, 60, no. 237 (1950): 81-91.

Khanin, G. I., Selyunin V. "Lukavaya tsifra [A Deceptive Figure]." Novyi mir, 1987, no. 2: 181-201.

Kornai, J. The Socialist System: the Political Economy of Communism. Oxford: Clarendon Press, 1992.

Kotowitz, Y. "Moral Hazard." In The New Palgrave: a Dictionary of Economics, Vol. 3, edited by J. Eatwell, M. Milgate, and P. Newman, 549-51. Basingstoke and London: Macmillan, 1987.

Kuromiya, H. Stalin's Industrial Revolution: Politics and Workers, 1928-1932. Cambridge: Cambridge University Press, 1988.

Malafeev, A. N. Istoriia tsenoobrazovaniia v SSSR [A History of Price Formation in the USSR]. Moscow: Mysl', 1964.

Moorsteen, R. Prices and production of machinery in the Soviet Union, 1928-1958.

Cambridge, MA: Harvard University Press, 1962.

Nove, A. “'1926/7' and All That.” Soviet Studies, 9, no. 2 (1957): 117-30.

- The Soviet Economy. London: Allen and Unwin, 1961.

Nutter, G. W. The Growth of Industrial Production in the Soviet Union. Princeton, NJ: National Bureau for Economic Research and Princeton University Press, 1962.

Pannell, K. E. "Preparing for War: the Organization of Soviet Central Planning." Paper to the All-University of California Group in Economic History Conference on Economic Transitions Between War and Peace. Santa Barbara, CA, 1997.

Pitzer, J. S. "The Tenability of the CIA Estimates of Soviet Economic Growth: a Comment." Journal of Comparative Economics, 14, no. 2 (1990): 301-14.

Ross, S. "The Economic Theory of Agency: the Principal's Problem." American Economic Review, 63, no. 2 (1973): 134-39.

Rossiiskii Gosudarstvennyi Arkhiv Ekonomiki [Russian State Economics Archive] (RGAE). Moscow.

Rotshtein, A. I. Problemy promyshlennoi statistiki [Problems of Industrial Statistics], Vol. 1. Leningrad: Gos. sots.-ekon. izdatel'stvo, 1936.

Seton, F. "Pre-war Soviet Prices in the Light of the 1941 Plan." Soviet Studies, 3, no. 4 (1952): 345-64.

Starovskii, V. "O metodike sopostavleniia ekonomicheskikh pokazatelei SSSR i SShA [On the Methodology of Comparison of Economic Indicators of the USSR and USA]." Voprosy ekonomiki, 1960, no. 4: 103-17.

Tsentral'noe Statisticheskoe Upravlenie SSSR (TsSU). Universal'nyi spravochnik tsen [Universal Handbook of Prices]. 3rd edn., Moscow: Gosstatizdat, 1928.

- Narodnoe khoziaistvo SSSR v 1967 godu [The National Economy of the USSR in 1967]. Moscow: Statistika, 1968.

Turetskii, I. "K probleme tsenovykh pokazatelei v plane [On the problem of price indicators in the plan]." Plan, 1934, no. 5: 38-41.

Turetskii, Sh. Ia. "Dlia chego planiruetsia produktsiia v neizmennykh tsen 1926-27 g. [Why Production is Planned in the Unchanged Prices of 1926-27]." Plan, 1935, no. 11: 62-64.

- Vnutripromyshlennoe nakoplenie v SSSR [Intra-Industry Accumulation in the USSR]. Moscow: Gospolitizdat, 1948. 
Voznesenskii, N.A. Izbrannye proizvedeniia [Selected Works]. Moscow: Politizdat, 1985. Wiles, P. J. D. The Political Economy of Communism. Oxford: Blackwell, 1962.

Williamson, O. E. The Mechanisms of Governance. Oxford: Oxford University Press, 1996. Yugow, A. "Economic Statistics in the USSR." Review of Economic Statistics, 29, no. 4 (1947): 242-46. 


\section{NoTES}

${ }^{1}$ For a variety of early western evaluations of the "unchanged prices of 1926/27" see Harris, "Appraisals"; Clark, "Russian Income"; Gerschenkron, "Soviet Indices"; Yugow, "Economics Statistics"; Dobb, "Further Appraisals"; Dobb, "Comment"; Kaser, "Soviet Planning"; Jasny, "Soviet Statistics"; Jasny, Soviet Economy; Jasny, Soviet Price System; Seton, "Pre-war Soviet Prices"; Hodgman, Soviet Industrial Production; Nove, “"1926/7' and All That"; Bergson, Real National Income; Nutter, Growth; and Wiles, Political Economy.

2 The subtitle of Ross, "Economic Theory".

${ }^{3}$ A proper appraisal of the role of the "unchanged" prices in hidden inflation of Soviet official real growth figures requires detailed comparison of Soviet official and western best-practice methodologies for evaluation of product change, and has substantial implications for the standard western studies of Soviet economic growth carried out by Abram Bergson, Richard Moorsteen, Raymond Powell, and others (see in particular Bergson, Real National Income). These issues are considered separately in a parallel study, Harrison, "Soviet Industrial Production".

${ }^{4}$ For a broad-focus discussion of agency problems in the Soviet administrative setting, see Gregory, Restructuring.

5 Kotowitz, "Moral Hazard".

${ }^{6}$ Williamson argues that the "nagging problems of incentives, controls, and bureaucracy" continued to be ignored in later theories of market socialism and state-socialist economic reform. For the transaction-costs approach to socialist economic organization see Williamson, Mechanisms, pp. 162-69.

${ }^{7}$ On "hidden action" and "hidden information" see Arrow, "Economics".

${ }^{8}$ For the soft budget constraint see Kornai, Socialist System, pp. 140-45.

${ }^{9}$ This description draws on many sources, in particular Granick, Management; Berliner, Factory; Nove, Soviet economy; Gregory, Restructuring; Kornai, Socialist System.

${ }^{10}$ On inter-enterprise contests see Pannell, "Preparing".

${ }^{11}$ Granick, Management, pp. 150-202; Berliner, Factory, pp. 25-56, 231-300.

${ }^{12}$ Kuromiya, Stalin's Industrial Revolution; Davies, Industrialisation.

${ }^{13}$ Williamson, Mechanisms, pp. 4-5 (emphasis added).

${ }^{14}$ Rotshtein, Problemy, p. 239.

${ }^{15}$ The explanation of the abandonment of 1913 provided by Sh. Turetskii, "Dlia chego planiruetsia produktsiia", p. 62, is redolent of the atmosphere of the time: "The very transition 
from unchanged prewar prices to unchanged prices of 1926/27 was a fact of huge political significance. This transition was met with a bayonet-charge by wreckers of every stripe. Separation from the prewar umbilicus in valuing output was perceived by Menshevik planners and statisticians as a blow against their attempts to use planning as a tool for restorationist and counterrevolutionary work." The serious point which Turetskii went on to make was that $1926 / 27$ was a good base year because it was marked by a normalization of price relativities after the monetary reform of 1924, including some success for government price controls aimed at a relative lowering of industrial product prices and costs.

${ }^{16}$ Davies, "Industry", p. 139.

17 "[S] upposed to be", because even for products actually produced in 1926/27, it was said that the "unchanged" price was often based on some other year (I. Turetskii, "K probleme", p. 39).

${ }^{18}$ For official recognition of this problem see Rossiiskii Gosudarstvennyi Arkhiv Ekonomiki, fond 4372, opis' 23, delo 76, list'ia 3-4 [hereafter RGAE, 4372/23/76, folios 3-4] (Mezhlauk to Sovnarkom, 25 October 1934).

${ }^{19}$ RGAE, 4372/23/76, folios 14-27 (Mezhlauk to Sovnarkom, 25 October 1934); 4372/33/154, folio 43 (Narkompishcheprom (People's Commissariat of the Food Industry) to Gosplan, 23 February 1935). For example RGAE, 4372/31/104, folios 302-301, a circular within Narkomles (the People's Commissariat of the Timber Industry), not dated but 1933, informing of a new schedule of "unchanged" prices for use in 1934, explaining that the old "unchanged" prices, differentiated by region but not by product quality, had understated growth both by undervaluing the products of the northern and eastern regions, and by failing to reflect the increase in high-quality products; this claim was repeated in circulating the 1935 handbook (RGAE, 4372/33/156, folios 360-360ob.).

${ }^{20}$ Rotshtein, Problemy, p. 246. By 1940, according to Sh. Turetskii, Vnutripromyshlennoe nakoplenie, p. 380, only 30 percent of machinery output was directly comparable with the product profile of 1932. According to sources cited respectively by Jasny, Soviet Price System, p. 105, and Nove, “"1926/7' and All That”, p. 119, the degree of continuity of machinery output from one year to the next was estimated in the late 1940s at only 50-60 percent; in the year 1953, over one quarter of machinery products of the typical machinebuilding enterprise was said not to be comparable with the previous year's output. In the 1970s, unique products accounted for half the output of the machine-building and metalworking (MBMW) sector; in addition, between 10 and 17 percent of the MBMW product profile was renewed annually according to CIA, Comparing, pp. 6-7.

${ }^{21}$ Rotshtein, Problemy, p. 241.

${ }^{22}$ I. Turetskii, "K probleme", p. 39; Sh. Turetskii, "Dlia chego planiruetsia produktsiia", p. 63; Rotshtein, Problemy, pp. 241-43; Gerschenkron, "Soviet Indices", pp. 219-20; Jasny, Soviet Price System, pp. 96-97; Nutter, Growth, pp. 111, 154. A countervailing influence in the early 1930s, however, was the subsidy of machinery production and prices. This was a factor which some western economists took more seriously than others. Dobb, "Further Appraisals", p. 35, argued this in a strenuous defence of the official Soviet practice, and 
Bergson, Real National Income, p. 185, was willing to grant it some credence in the light of the relative stability of machinery prices observed in the 1930s.

${ }^{23}$ Sh. Turetskii, "Dlia chego planiruetsia produktsiia”, p. 63.

${ }^{24}$ As was recognized by Seton, "Pre-war Soviet Prices”, pp. 352-53; Nove, ““1926/7” and All That", pp. 119, 121.

${ }^{25}$ RGAE, 4372/31/66, folios 146-145 (memo to Rozovskii (chief of sector for machinebuilding) and Turetskii "On methods of computation of 1926/27 prices for new products", 7 September 1933).

${ }^{26}$ Berliner, Innovation Decision, pp. 375-80; see also Nutter, Growth, p. 154; CIA, Analysis, p. 2; CIA, Comparing, pp. 6-7; Pitzer, “Tenability", p. 307. The seller's market did not operate in defence industry, however, and simulated innovation was ruled out by the power of the purchaser (the Defence Ministry) to control product specifications and reject products. In defence industry, therefore, producer opportunism took other forms. See Harrison and Simonov, "Voenpriemka".

${ }^{27}$ Moorsteen, Prices, p. 51: "in order to economize costs, models once established in production are often manufactured without significant change over long periods".

${ }^{28}$ Berliner, Innovation Decision.

${ }^{29}$ The GNP deflators are calculated from Bergson, Real National Income, pp. 46, 48, 130; for expenditure components see ibid., p. 186.

${ }^{30}$ This was pointed out by Gerschenkron, "Soviet Indices", pp. 219-20; Jasny, Soviet Price System, pp. 96-97; Nutter, Growth, p. 154.

${ }^{31}$ At this point my argument encroaches on the territory of hidden inflation. The connection is that the coefficient of nominal GVO in equation 3 is the reciprocal of a price index -- but a distorted one. For fuller discussion see Harrison, "Soviet Industrial Production".

${ }^{32}$ I. Turetskii, "K probleme"; Sh. Turetskii, "Dlia chego planiruetsia produktsiia"; Rotshtein, Problemy.

${ }^{33}$ RGAE, 4372/23/76, folios 1-2 (Mezhlauk to Sovnarkom, 25 October 1934). RGAE, 4372/32/84, folios 9-5 ("Spravochnik neizmennykh tsen 26-27 goda i popravochnykh koefitsientov dlia tsentralizovannogo planirovaniia", no date) lists ratios of commodity prices for artisan industry in 1932 relative to "unchanged prices of 1926/27" for state industry. For 218 individual commodities listed the unweighted mean ratio was 198 percent $( \pm$ a standard deviation of 107 percent); only eight commodities showed a 1932 price below the "1926/27" level.

${ }^{34}$ RGAE, 4372/32/84, folio 113 (Gosplan "Instructions", 21 February 1935). For a retrospective account of the process, see RGAE, 4372/38/270, folio 2 (Sobol', chief of TsUNKhU department of balance of national economy, to Iampol'skii of Gosplan, 5 
December 1938, “On planning and accounting for production in unchanged prices of 1926/27”). For the published story, see Rotshtein, Problemy, pp. 248-49.

${ }^{35}$ RGAE, 4372/31/66, folios 155-154 (draft "Methodological instructions", 26 December 1933). Also RGAE, 4372/23/76, folios 44-45 (draft decree on 1926/27 prices, 21 September 1934), and 1562/1/809, folios 17-5 and 184-175 (Mezhlauk to Sovnarkom "Ob uporiadochenii i oformlenii tsennikov neizmennykh tsen 1926/27 g.", 1 October and 2 November 1934),

${ }^{36}$ Sh. Turetskii, "Dlia chego planiruetsia produktsiia", pp. 62-64.

${ }^{37}$ Nove, ““1926/7' and All That”, p. 120. Seton, "Pre-war Soviet Prices”, p. 353, argued: "It must have been mainly to counteract this tendency that the 'stable-ruble' price structure was revised; the alterations made were therefore presumably in the direction of raising the prices of goods whose weight in the total fulfilment figure had previously been unduly small. The alternative course of reducing the 'stable-ruble' prices of over-valued goods would have had the depressing effect of requiring a general lowering of production targets. It is quite probable, therefore, that the periodic revisions of the stable price base actually reinforced the inflationary bias of the figures".

${ }^{38}$ RGAE, 4372/23/76, folios 44-45 (draft decree on 1926/27 prices).

${ }^{39}$ RGAE, 4372/23/76, folios 22-23; see also ibid., folio 5.

${ }^{40}$ RGAE, 4372/23/76, folios 42-43.

${ }^{41}$ RGAE, 4372/33/154, folio 103.

${ }^{42}$ Malafeev, Istoriia tsenoobrazovaniia, p. 185.

${ }^{43}$ RGAE, 4372/23/76, folios 48-50, "List of 1926/27 price schedules registered by Gosplan and TsUNKhU" (appendix to draft Sovnarkom decree of September 1934 "Ob oformlenii tsennikov neizmennykh tsen 1926/27 g."). By way of self-exculpation I note that the recomputation of postwar United States price indexes for durable goods by Gordon, Measurement, which covered more than 25,000 price quotations drawn from trade catalogues and periodicals, required a generation of research assistants and 15 years' work (ibid., p. 7). Note, in addition, that under Soviet seller's-market conditions goods were specified in less detail than in the United States buyer's market since there was no need for the producer to win over the buyer. Therefore, the price and product information available to modern researchers from Soviet historical documentation is both greater in quantity and inferior in detail compared with US sources.

${ }^{44}$ RGAE, 4372/23/76, folios 3-4; 4372/23/76, folios 14-27; 4372/23/76, folio 19; 4372/35/58, folios 20-21

${ }^{45}$ RGAE, 4372/23/76, folio 19 (Mezhlauk to Sovnarkom). However, some part of this spread might be understood as a Gerschenkron effect, with relative prices of more highly fabricated goods negatively influenced by relative development level in cross-country comparison. 
${ }^{46}$ RGAE, 4372/23/76, folio 5.

${ }^{47}$ RGAE, 4372/23/76, folio $19 ; 4372 / 35 / 58$, folios $20-21$;

${ }^{48}$ RGAE, 4372/38/270, folio 3 (Sobol' to Iampol'skii, 5 December 1938).

${ }^{49}$ Compare the interpretation of the 1966 wholesale price reform offered by Berliner, "Planning", pp. 355-56.

${ }^{50}$ Dobb, "Further Appraisals", p. 35, and "Comment", pp. 21-22, alone among western observers, found the reforms of 1934 and 1935 a convincing solution, arguing that the new procedures "removed criticism on this particular score". This was clearly overoptimistic; the chaining of new products into gross output indexes at high prices based on temporarily inflated costs, and the regrading of existing products as new in order to reprice them at a higher level, persisted even under the new arrangements of the post-1950 era according to CIA, Comparing, pp. 6-7.

${ }^{51}$ RGAE, 4372/32/85, folios 76 and 5-3 (1937); 4372/92/82, folios 53-54 (1937); 4372/38/270, folio 3 (1938); 1562/3/553, folios 80-81 (1938); 1562/329/297, folios $92-5$ (1940); 4372/92/348, folios 25-30 (1940).

${ }^{52}$ RGAE, 4372/35/58, folio 11 (protocol no. 48 of the commission on 1926/27 prices, 4 April 1937).

${ }^{53}$ RGAE, 4372/35/58, folios 20-21. In its decree no. 53, 15 June 1937, the commission on $1926 / 27$ prices acceded to a ministerial reversal of an order to lower "unchanged" prices for leather footwear on the grounds that otherwise the ministerial GVO would be excessively deflated.

${ }^{54}$ RGAE, 1562/3/553, folios 81-82; this document is not dated, but cites a letter from Narkommash to TsUNKhU of 28 January 1938.

${ }^{55}$ Rotshtein, Problemy, p. 242.

${ }^{56}$ The official price indexes were published in TsSU, Nar. khoz. 1967, p. 227.

${ }^{57}$ For the stages of the review see RGAE, 4372/47/4, folios 105-8 (Malyshev to Voznesenskii, 25 November 1947); 4372/47/1, folios 154-8 (protocol no. 47 of Gosplan, 15 December 1947); 4372/48/4, folios 180-1 (Kosiachenko, Starovskii, and Pautin to Voznesenskii, not dated but before 19 March 1948); 4372/48/1, folios 55-57 (protocol no. 11 of Gosplan, 20 March 1948); 4372/48/344, folios 15-17 (Sorokin to Voznesenskii, 13 May 1948).

${ }^{58}$ RGAE, 4372/48/3, folio 171 (Pautin, Ivanov, and Pisarev to the Council of Ministers, February 1948).

${ }^{59}$ RGAE, 4372/47/4, folio 106; RGAE, 4372/48/344, folios $15-17$. 
${ }^{60}$ RGAE, 4372/47/4, folio 105; RGAE, 4372/48/3, folios 171-172; RGAE, 4372/48/344, folio 16.

${ }^{61}$ RGAE, 1562/329/4592, folios 23-59 and 185-208, comprise correspondence including copies of all the 1947 symposium articles and Russian translations of Harris, "Appraisals", Clark, "Russian Income", and Yugow, "Economic Statistics"; an interview with Seymour Harris from the New York Times of 20 October 1947; and a Russian translation of Jasny, "Soviet Statistics", which appeared subsequently in 1950.

62 The quotation is from Voznesenskii on the fourth Five-Year Plan to the Supreme Soviet in March 1946 (Voznesenskii, Izbrannye proizvedeniia, p. 465).

${ }^{63}$ The proposal originated at the Gosplan meeting of 15 December 1947 (RGAE, 4372/47/1, folio 157); a draft decree written by planning officials Pautin, Ivanov, and Pisarev, with a dissenting opinion by the latter (RGAE, 4372/48/3, folios 170-77), was considered by Gosplan on 20 February 1948 (RGAE, 4372/48/1, folio 20). The final draft was sent to Stalin on 5 June (RGAE, 4372/48/13, folios 312-48) and promulgated by the Council of Ministers on 28 July as Decree no. 2783 "On liquidation of the system of state subsidies and increase of wholesale prices of products of a number of branches of heavy industry and charges for rail transport" (Postanovleniia Soveta Ministrov SSSR za iul' 1948. Vtoraia chast' (dlia sluzhevnogo pol'zovaniia), pp. 1069-76).

${ }^{64}$ RGAE, 4372/48/3, folio 177.

${ }^{65}$ TsSU, Nar. khoz. 1967, p. 227.

${ }^{66}$ It is still hard to improve on the interpretation of Kaser, "Débat", pp. 566-67.

${ }^{67}$ Starovskii, "O metodike", p. 111.

${ }^{68}$ Khanin and Seliunin, "Lukovaia tsifra". 
TABLE 1

SOVIET INDUSTRIAL PRODUCTION

AND NATIONAL INCOME, 1928-1950,

SELECTED YEARS: OFFICIAL FIGURES

(billion rubles and "unchanged prices of 1926/27”)

\begin{tabular}{lrr}
\hline Year & $\begin{array}{l}\text { Industrial } \\
\text { Production }\end{array}$ & $\begin{array}{l}\text { National } \\
\text { Income }\end{array}$ \\
\hline & & \\
1928 & 21.8 & 25.0 \\
1937 & 95.5 & 96.3 \\
1940 & 137.5 & 125.5 \\
1948 & 163.0 & 144.0 \\
1950 (prelim.) & 235.0 & 205.0 \\
\hline
\end{tabular}

Note: Industrial production is gross output

(including double-counted intermediate

products); national income is gross output less

"productive [intermediate] consumption".

Hence the apparent size disparity of industry

relative to the economy as a whole.

Source: Jasny, Soviet Economy, p. 7. 
TABLE 2

GROSS VALUE OF OUTPUT OF SOVIET INDUSTRY AT

“UNCHANGED” AND PREVAILING PRICES, 1935

(million rubles)

\begin{tabular}{lrrr}
\hline \hline $\begin{array}{l}\text { People's } \\
\text { Commissariat }\end{array}$ & $\begin{array}{l}\text { At } \\
\text { "Unchanged" } \\
\text { Prices }\end{array}$ & $\begin{array}{l}\text { At Prevailing } \\
\text { Wholesale } \\
\text { Prices }\end{array}$ & Ratio, (1) $\div(2)$ \\
& $(1)$ & $(2)$ & $(3)$ \\
Heavy industry & 25,107 & 25,614 & 0.98 \\
Light industry & 5,910 & 12,707 & 0.47 \\
Food industry & 6,591 & 16,522 & 0.40 \\
Other industry & 10,312 & 15,860 & 0.65 \\
Total & 47,919 & 70,703 & 0.68 \\
\hline
\end{tabular}

Note: "Other" industry comprises the commissariats for the timber and local industries, procurements, and cinematography.

Source: calculated from RGAE, 1562/51/220, folio 10. 
TABLE 3

RATIO OF "UNCHANGED" PRICES TO

PREVAILING WHOLESALE PRICES IN

SOVIET INDUSTRY, 1935-1936

\begin{tabular}{|c|c|c|}
\hline People's Commissariat & 1935 & 936 \\
\hline Heavy industry & 0.98 & 0.83 \\
\hline Othe & & 0.43 \\
\hline Total & 0.68 & 0.57 \\
\hline \multicolumn{3}{|c|}{$\begin{array}{l}\text { Notes: In this table "other" industry } \\
\text { comprises the commissariats for the light, } \\
\text { food, timber, and local industries, } \\
\text { procurements, and cinematography. } \\
\text { Comparisons within this group between the } \\
\text { two years are disturbed by the transfer of } \\
\text { some enterprises from local industry to light } \\
\text { industry. } \\
\text { Source: } 1935 \text {, as table } 2 ; 1936 \text { calculated } \\
\text { similarly from RGAE, } 1562 / 51 / 220 \text {, folio } 1 \text {. }\end{array}$} \\
\hline
\end{tabular}


TABLE 4

MEAN DIFFERENCES IN NATURAL

LOGARITHMS OF “UNCHANGED” PRICES

BETWEEN SAMPLES OF MATCHED

COMMODITIES, VARIOUS YEARS

Sample $4.1\left(1928\right.$ and 1935) $\quad \ln \left(p_{28}\right) \quad \ln \left(p_{35}\right)$

Mean

Variance

Observations

Pearson correlation

Hypothesized mean difference

Degrees of freedom

$t$-statistic

$P(T \leq t)$ one-tail

$t$ critical one-tail

$P(T \leq t)$ two-tail

$t$ critical two-tail
$5.912 \quad 5.725$

$5.675 \quad 5.550$

$32 \quad 32$

0.966

0

31

1.719

0.048

1.696

0.096

2.040

Data sources: 1928 from TsSU, Universal'nyi spravochnik; 1935 from RGAE, 1562/33/154, folios $175-53$ (32 basic products directly matched from these two price schedules) 


\begin{tabular}{lrrrrrr} 
& \multicolumn{2}{c}{$(\mathrm{A})$} & & \multicolumn{2}{c}{$(\mathrm{B})$} \\
\cline { 2 - 3 } \cline { 5 - 6 } & & & & & \\
& $\ln ($ mean $)$ & $\ln ($ new $)$ & & $\ln ($ mean $)$ & $\ln ($ new $)$ \\
\hline Mean & 3.838 & 3.934 & & 3.699 & 3.697 \\
Variance & 2.639 & 3.164 & & 2.935 & 3.132 \\
Observations & 36 & 36 & & 31 & 31 \\
Pearson correlation & 0.968 & & & 0.995 & \\
Hypothesized mean difference & 0 & & & 0 & 30 \\
Degrees of freedom & 35 & & & 0.060 & \\
$t$-statistic & -1.259 & & & 0.476 & \\
$P(T \leq t)$ one-tail & 0.108 & & & 1.697 & \\
$t$ critical one-tail & 1.690 & & & 0.953 & \\
$P(T \leq t)$ two-tail & 0.216 & & & 2.042 & \\
$t$ critical two-tail & 2.030 & &
\end{tabular}

Notes: The source specifies the transition from multiple to unified

"unchanged" prices in the heavy and timber industries; 31 separate basic products were covered, and, additionally, the old single price for plywood was replaced by 5 separate product prices graded by quality. In the table the "new unchanged" prices of the first 32 products are compared with the arithmetic means of the corresponding "old" maxima and minima for each product. Sample (A) includes, and sample (B) excludes plywood products. For the 5 plywood products each paired observation links the single "old" price with a different "new" quality-graded price.

Data source: RGAE, 4372/23/76, folios 9-13 (Spravka "O vazhneishikh popravkakh, vnosimykh $\mathrm{v}$ deistvuiushchie tseny 1926/27 g. po promyshlennym narkomatam", not dated, but apparently September or October 1934). 
TABLE 4 (cont.)

Sample 4.3 (1934)

$\ln ($ old $) \quad \ln ($ new $)$

Mean

$5.157 \quad 5.046$

Variance

$9.892 \quad 9.070$

Observations

32

32

Pearson correlation

0.989

Hypothesized mean difference

0

Degrees of freedom

31

$t$-statistic

1.294

$P(T \leq t)$ one-tail

0.103

$t$ critical one-tail

1.696

$P(T \leq t)$ two-tail

0.205

$t$ critical two-tail

2.040

Data source: RGAE, 4372/31/105, folios 173-168

(September 1934) -- a document of the People's

Commissariat of the Food Industry which details

revisions to "unchanged" prices including 32 directly

matched commodities. 
TABLE 5

RATIO OF "UNCHANGED" PRICES TO

PREVAILING WHOLESALE PRICES IN

SOVIET INDUSTRY, 1940-1950

$1940 \quad 1945 \quad 1950$

\begin{tabular}{llll} 
Group "A" & 0.57 & 0.80 & 0.51 \\
military products & 0.89 & 1.04 & 0.95 \\
civilian products & 0.50 & 0.64 & 0.48 \\
Group "B" & 0.22 & 0.19 & 0.20 \\
Total & 0.35 & 0.46 & 0.34 \\
\hline
\end{tabular}

Notes: Group "A" products are means of production (civilian products) or destruction (military products); group "B" products are means of consumption. The original gives a figure for civilian production of group " $A$ " in 1950 of 394 billion rubles at prevailing prices where 294 billion was clearly intended.

Source: calculated as table 2 from RGAE, 4372/94/945, folio 7 . 